\title{
APPLICATION OF COST-BENEFIT AND BREAK-EVEN ANALYSIS FOR THE DEVELOPMENT OF STINGLESS BEES FARMING IN MALAYSIA
}

\author{
Ilmas Abdurofi* \\ Universitas Gadjah Mada, Indonesia \\ Mohd Mansor Ismail \\ Univerisiti Putra Malaysia, Malaysia \\ Normaz Wana Ismail \\ Univerisiti Putra Malaysia, Malaysia \\ Amin Mahir Abdullah \\ Universiti Putra Malaysia, Malaysia
}

\begin{abstract}
The information about the economic and financial aspects of stingless bees farming is still limited along with some issues of high selling price and expenses. Therefore, the study initially aims to describe comprehensively cost-benefit, and break-even analysis of stingless bees farming in Malaysia. The study uses primary data and employs about 124 stingless beekeepers in all regions in Malaysia as number observation. The sampling method uses non-probability sampling, while the costing analysis, net return, input-output ratio, cost-benefit ratio and breakeven analysis are applied as analytical techniques. As a result, the stingless bees farming may generate considerable earnings, mainly in the area of Peninsular Malaysia, whilst the Sarawak region shows efficient cost of production in the break-even point. Furthermore, labor expense constitutes a predominant concern in the production and hive investment is required as high capital expenditure. The study recommended that the government and beekeepers should find alternative hive systems in order to reduce cost and focus on the massive production of stingless honey bees in the Sarawak area, while Peninsular Malaysia may turn into a main concentration of trading and marketing honey products.
\end{abstract}

Keywords: Stingless Bees Farming, Cost and Benefit Analysis, Break-Even Analysis, Malaysia.

Received: 16 June 2019

Accepted: 10 May 2021

https://doi.org/10.33736/ijbs.3763.2021

\section{INTRODUCTION}

Beekeeping industry contributes essential influences in the development of socio-economic and forest conservation in Malaysia. The product of the beekeeping industry not only focusses on honey production but also other beneficial outputs as pollen, brood, propolis, bees-wax and bee

\footnotetext{
* Corresponding author: Department of Agricultural Socio-Economics, Faculty of Agriculture, Universitas Gadjah Mada, 55281, Bulaksumur-Yogyakarta, Indonesia; Tel: +62 82129767609; Email: ilmas.abdurofi@ugm.ac.id
} 
venom. Moreover, the industry may also generate additional source of income, since it was estimated by selling bees' product, millions of revenues may provide into the industry (Ismail \& Radam, 2010). Hence, it is necessary to generate income with high potential activity in the beekeeping industry. The common species of bees are Apis cerana and Apis mellifera. The annual yield from the Apis cerana or local bees is roughly about $5-9 \mathrm{~kg}$, while Apis mellifera or the imported bee tends to produce up to $50 \mathrm{~kg}$ per colony in a year. However, this species is prone to pests and diseases. Then, the Trigona or stingless bees emerged as a new activity in the beekeeping industry that is expected to complement natural honey production and pollination services in Malaysia (Ismail, 2014).

Stingless bees are active all year round; they do not sting but will defend by biting if their nest is disturbed. They usually nest in hollow trunks, tree branches, underground cavities or rock crevices, nevertheless they have also been encountered in wall cavities, old rubbish bins, water meters, and storage drums. They are widely distributed in the tropical and temperate regions of the world (Roubik, 2006). As Figure 1 below, the red line illustrated the inhabited area of stingless bees in the wide world. The stingless bees are solely adapted in the tropical area as in the tropic of cancer (Northern Tropic) and Capricorn (Southern Tropic). Some countries which have the opportunity to develop stingless bees rearing are several areas in South America, Central Africa, Middle Eastern, Southeast Asia and West Australia, while the existence of stingless bees is excessively suitable in the climate of all regions in Malaysia. In terms of its benefits, Andualem (2014) studied that stingless honey bees are widely used for traditional treatment like respiratory ailments, surface infection and other diseases. It might also be effective to treat different infectious diseases with that are low concentration. Stingless honey bees also have better medical potency than common honey, while the antimicrobial activity of stingless honey bees against tested pathogens is better than other types of honey. Furthermore, stingless bees are common pollinators in the Malaysian agricultural ecosystem, their contribution to human's socio-economy has yet to be quantified or even appreciated. In fact, there has a complete study carried out on using stingless bees to enhance crop or horticultural production (Jalil \& Shuib, 2014).

Figure 1: Stingless Bees Zone

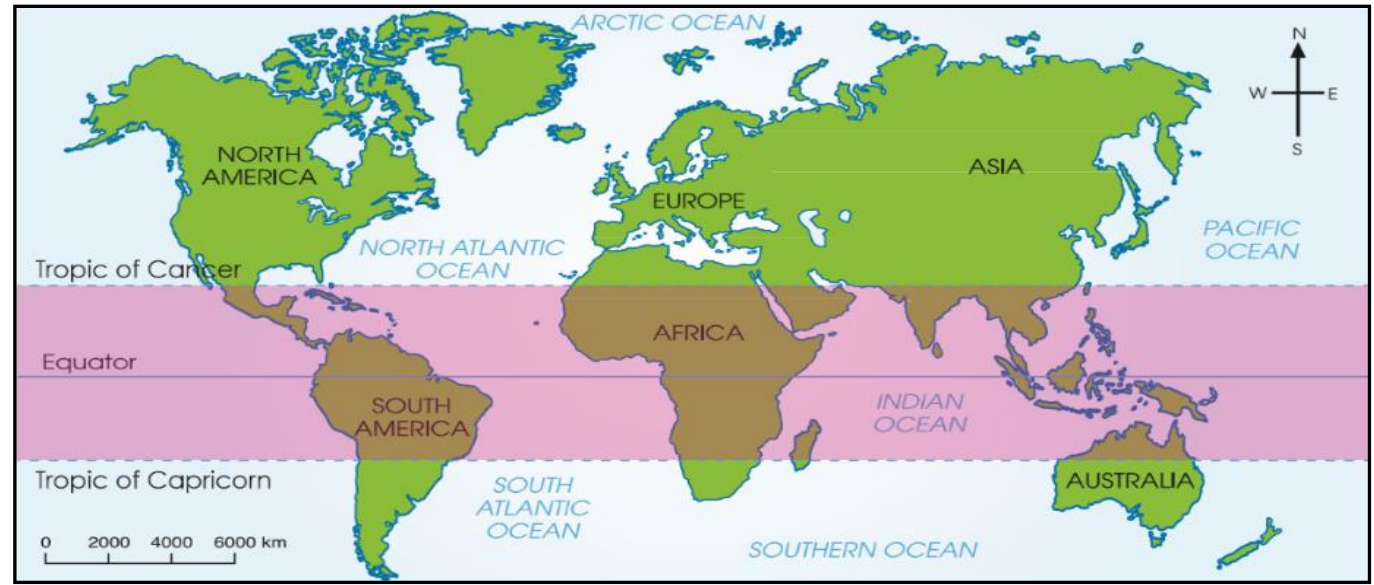

Source: Kwapong et al. (2010) 
In Malaysia, the business emphasis of stingless bees focuses on honey production. Majority of the farm management still applies the conventional approach without employing a huge number of labour and applying sophisticated technology (Jalil \& Roubik, 2016). Due to the tremendous benefits of stingless honey bees and price competition in the honey market, the demand for stingless honey bees for the local consumption was increased. However, the supply of honey is still limited. According to Jalil (2016), the price of the stingless honey bees is highly expensive than common honey. While, purchasing directly stingless honey bees from a producer, it costs about RM 150 - 200 per kilogram, then price of stingless honey bees in the market is between RM 200- 500 per kilogram (Table 1), indicating there is a huge gap in the selling price between in the market and farm level. Hence, because of the high cost of stingless honey bees in the market and farm, the study of cost-benefit analysis is highly essential to describe comprehensively the cost and production of stingless honey bees in Malaysia.

Table 1: Price Comparison between Stingless Honey Bees and Common Honey Bees

\begin{tabular}{lll}
\hline \hline Attributes & Trigona Honey Bees & Apis Honey Bees \\
\hline Price of hives / colonies & RM 500-1,500 & RM 700-900 \\
Producer price/kg & RM $150-200$ & RM 30 - 40 \\
Domestic market price per kg & RM 200 - 500 & RM 60 - 90 \\
Production per hive & $0.5-1 \mathrm{~kg} /$ month & $4-6 \mathrm{~kg} /$ month \\
\hline \hline
\end{tabular}

Source: Jalil (2016)

\section{LITERATURE REVIEW}

Limited resources in investigating specifically the stingless bees farming or Meliponiculture in financial and economic aspects have emerged. Initially, a study by Budiaman (2016) on the financial feasibility of agroforestry for Trigona spp, led to the conclusion that the project farming of Trigona bees is economically viable. The methods of data collection and sampling techniques used direct observation and purposive sampling with 20 percent of sampling intensity. The economic data as production, cost, and income were completed by spreading the questionnaire and focus group discussion. Another study on the beekeeping industry as a whole was conducted by Narjes (2009). Five setups for the economic exploitation of bees were identified to potentially be adopted by rural smallholders in the study area, namely the Apicultures of A. mellifera and $A$. cerana, honey hunting of A. dorsata, the meliponiculture of Trigona spp., and hive baiting for A. cerana. The methods were assessed and compared based on a cost-benefit analysis and a subsequent risk analysis.

\section{METHODOLOGY}

The study focuses initially on actual data from beekeepers of stingless bee farms in Malaysia and compares among three regions namely Peninsular Malaysia, Sabah and Sarawak. The data collected were primary in nature, and were collected by a team of researchers/enumerators from the Institute of Agricultural and Food Policy Studies, Universiti Putra Malaysia. Data collection was performed by distributing questionnaires and face to face interviews. Besides, beekeepers' production reports were secondary data in conjunction with the input-output cost farm's initial 
investment. The study applies expert/judgemental sampling that derived from non-probability sampling. The target sample is only beekeepers who focus on rearing commercialized stingless bee farming that it was categorized by some experts of stingless bees in Malaysia. Thus, the study finally employs 124 stingless beekeepers in Malaysia.

\subsection{Analytical Techniques}

The methods and formulas for calculating costs and benefits analysis commonly discussed in farm management literature such as Boelje and Eidman (1984); Olukosi and Erhabor (1987); Nurunnaher, Rahman and Ali (2003); Abdurofi, Ismail, Abu-Wahab \& Gabdo (2017); Ndaliman and Bala (2007) as:

Revenue per unit is assumed to remain constant, while total revenue is attained by multiplying quantity of output and price per unit. Then, total revenue fluctuates in direct proportion to the level of activity or volume. Total revenue of stingless bee's honey farm was illustrated as:

$$
\mathrm{TR}=\mathrm{Q} \times \mathrm{P}
$$

Wherein,
TR: Total revenue (RM)
Q: Total honey production $(\mathrm{Kg})$
P: Price (RM)

Total fixed costs are the amount of cost that should be spent, although there is no production. Fixed costs include both fixed manufacturing overhead and administrative expenses such as utility, electricity, water and salary.

Depreciation cost assumes reallocating the cost of tangible assets over its useful life that is expected to be utilized during the projection. This study uses straight-line method in order to compute depreciation cost as the formula:

$$
\text { Depreciation Cost }=\frac{\text { Cost of Assets-Salvage Value }}{\text { Estimated Useful Life }}
$$

Wherein,

Salvage value is estimated resale value of capital expenditure / asset at the end of useful life.

, total variable cost fluctuates in direct proportion to the level of activity or volume. Variable production costs include direct material, direct labor, variable overhead and variable selling costs that include charges for items. Furthermore, this study also computes the marginal cost per kg to determine the amount of variable cost in producing $1 \mathrm{~kg}$ of honey. Then, marginal costs or variable cost per kg of stingless bee' honey was formulated as:

$$
\mathrm{MC}=\frac{\Delta \mathrm{TC}}{\Delta \mathrm{Q}}
$$

Wherein,

$$
\begin{aligned}
& \mathrm{MC}=\text { Marginal cost } \\
& \triangle=\text { Change }
\end{aligned}
$$




$$
\begin{aligned}
& \mathrm{Q}=\text { Quantity of honey } \\
& \mathrm{TC}=\text { Total cost }
\end{aligned}
$$

While, total cost of stingless bee's honey farm was illustrated as:

Wherein,

$$
\mathrm{TC}=\mathrm{TFC}+\mathrm{TVC}+\mathrm{TDC}
$$

$$
\begin{aligned}
& \text { TC }=\text { Total cost } \\
& \text { TFC }=\text { Total fixed Cost } \\
& \text { TVC }=\text { Total variable cost } \\
& \text { TDC }=\text { Total depreciation cost }
\end{aligned}
$$

Net profit is a financial benefit of the project in which the revenue exceeded total expenses. Net profit can be categorized as earnings before tax and earnings after tax, which depends on tax implication to the business. The equations are:

$$
\begin{gathered}
\mathrm{EBT}=\mathrm{TR}-\mathrm{TC} \\
\mathrm{EAT}=\mathrm{TR}-(\mathrm{TC}+\mathrm{Tax})
\end{gathered}
$$

Wherein,

$$
\begin{aligned}
& \text { EBT }=\text { Earnings before tax } \\
& \text { EAT }=\text { Earnings after tax } \\
& \text { TR }=\text { Total revenue } \\
& \text { TC }=\text { Total cost }
\end{aligned}
$$

Input-Output Ratio and Cost-Benefit Ratio define the relationship among cost, while the benefit and income is explained by the application of ratio. The input-output ratio determines the comparison between income and cost, while the cost-benefit ratio opposes the net profit (benefit) with a cost. If the input-output ratio is greater than 1 and the cost-benefit ratio is above zero, it can be evaluated that the farm profitability is presented.

$$
\begin{gathered}
\text { Input }- \text { Output Ratio }=\frac{\text { Total Income }}{\text { Total Cost }} \\
\text { Cost }- \text { Benefit Ratio }=\frac{\text { Net Profit }}{\text { Total Cost }}
\end{gathered}
$$

The break-even point assumes the level of business activity either in units or ringgits which the total revenue is equal total cost and determines common guidelines for business decision-making (Pollack, 1995). According to Berryman and Nobe (1999) break-even evaluates the firm desire's profit level, potential price and the impact of price changes. Furthermore, break-even also describes the relation between sales volume and profitability. The formula approach of break-even point applies algebraic equation as:

Wherein,

$$
R(X)-V C(X)-F C=P
$$

$\mathrm{R}=$ Revenue (selling price per unit)

$\mathrm{X}=$ Volume

$\mathrm{VC}=$ Variable cost per unit / marginal cost 
$\mathrm{VC}(\mathrm{X})=$ Total variable cost

$\mathrm{FC}=$ Total fixed cost

$\mathrm{P}=$ Total Profit

Then, by elucidating the above equation, break-even point per unit / $\mathrm{kg}$ can be applied by solving the equation of $\mathrm{X}$ as:

$$
\begin{aligned}
\mathrm{R}(\mathrm{X})-\mathrm{VC}(\mathrm{X})-\mathrm{FC} & =\mathrm{RM} 0 \\
\mathrm{R}(\mathrm{X})-\mathrm{VC}(\mathrm{X}) & =\mathrm{FC} \\
(\mathrm{R}-\mathrm{VC})(\mathrm{X}) & =\mathrm{FC} \\
\mathrm{X} & =\mathrm{FC}:(\mathrm{R}-\mathrm{VC})
\end{aligned}
$$

Thus, break-even volume equals total fixed cost divided by revenue per unit/ $\mathrm{kg}$ minus the variable cost per unit $/ \mathrm{kg}$. Furthermore, the break-even chart indicates graphically the relationship profit and losses at a different level of sales volume. Figure 3.2 below illustrated the framework of break-even analysis of the cost and benefit.

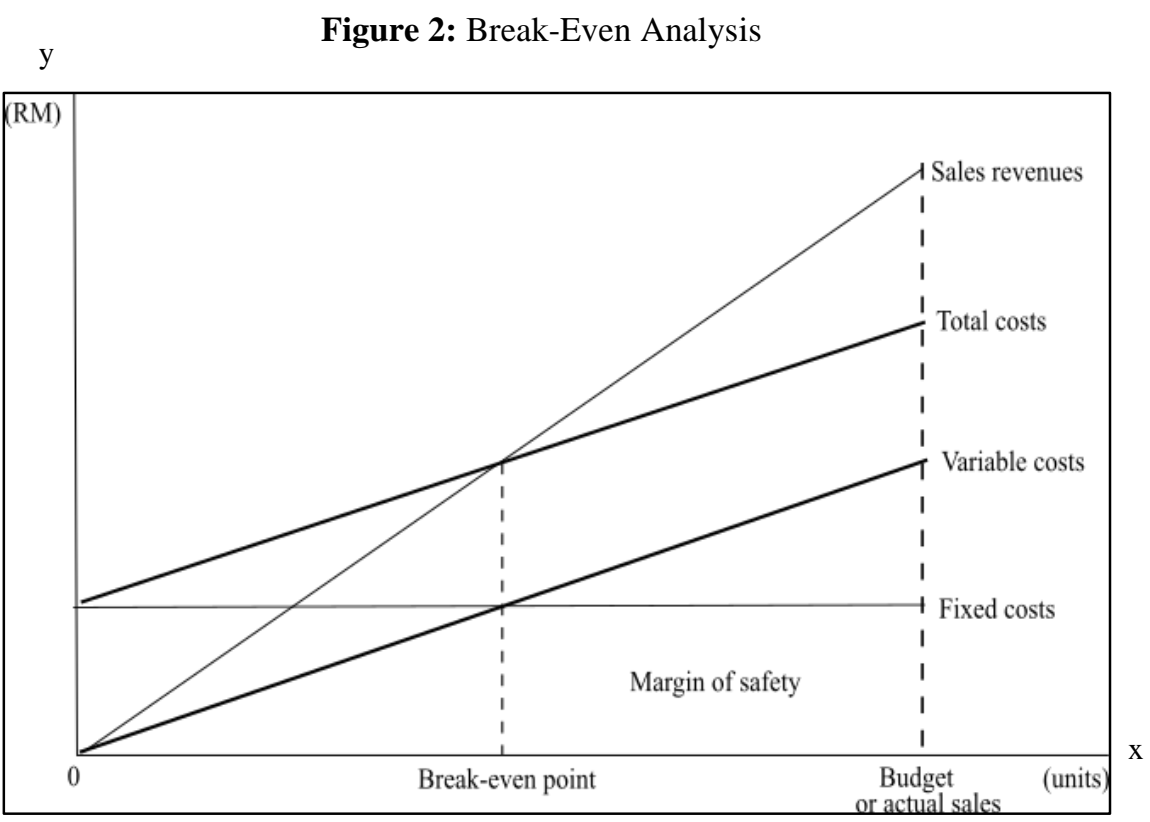

Source: Powers (1987)

Figure 2 above may be illustrated if the sales revenue is less than total cost, the losses are incurred. The Intersection of the sales revenue line and total cost line, indicating no profit or loss is occurred (break-even). Variable cost is related directly to the output, while the fixed cost is constant in the range of output produced. Then, the total cost line is a combination of fixed and variable cost lines. The total cost line would have parallel pattern with the variable cost line since it depends on the volume produced. Furthermore, margin safety is the extra amount of sales that are expected to be generated. 


\section{RESULTS AND DISCUSSION}

The Table 2 below presents socio-economic and farm background of stingless beekeepers in Malaysia. According to Jalil and Roubik, (2016) a stingless bees should be planned in the optimum use of a surrounding area, implementing colonies may be based on a minimum of $2 \mathrm{~m}^{2}$ of space between other colonies, it requires $4 \mathrm{~m}^{2}$ for a single colony to put comfortably and working on 1:4 ratio for the allocated planting area as $16 \mathrm{~m}^{2}$ for one hive, hence the capacity of 200 hives requires minimum more than 1 acre. Based on the result of Table 2, on average, beekeepers used about 2.07 acres to start a business of stingless bee honey in Malaysia. While, beekeepers in Sabah, utilized a huge size of land to allocate hives (2.57 acres), comparing with other regions. In terms of number of hives (colonies), region of Peninsular Malaysia bought more hives as 129 hives for the initial investment followed by Sarawak 85 hives and Sabah 41 hives respectively. However, the average number of the colony in Malaysia was 115 hives, indicating the allocation of 2.03 acres may be utilized to preserve approximately 115 colonies in Malaysia.

Next, the total production of honey results $469.87 \mathrm{~kg} / \mathrm{year}$ in Malaysia, wherein, Peninsular Malaysia constituted as a highest honey production among other regions $(514.92 \mathrm{~kg} / \mathrm{year})$. Then, the various figure of selling price was considerably different among regions. The selling price of honey per kg showed less expensive in Sabah (RM 105.50 per kg) and Peninsular Malaysia offered slightly expensive in giving a price of honey as RM $240.50 / \mathrm{kg}$. However, average selling price of honey maintained at RM 158.06 for the whole Malaysia. Regarding age proportion, beekeepers who are age between 30 and 39 were eager to take up the project of stingless bee farms, constituting more than $30 \%$ for all regions, includes entire Malaysia. This is because the incentive provides by the government is for those aged 40 and below. Then, the majority of beekeepers were educated since the percentage who have diploma or degree certificate constituted more than $50 \%$ in Malaysia, nevertheless, the beekeepers in both Sabah and Sarawak were mostly receiving medium schooling. Subsequently, all beekeepers experienced in the stingless bee project for more than 1 year and considerably chosen of being part time worker in doing stingless bee project.

Table 2: Socioeconomic Attributes of Stingless Beekeepers

\begin{tabular}{|c|c|c|c|c|}
\hline Variables/Area & $\begin{array}{r}\text { Peninsular } \\
\text { Malaysia } \\
\end{array}$ & Sarawak & Sabah & Malaysia \\
\hline Land size (acres) & 2.02 & 1.50 & 2.57 & 2.07 \\
\hline Number of colony (hives) & 129 & 85 & 41 & 115 \\
\hline $\begin{array}{l}\text { Total honey production per } \\
\text { year }(\mathrm{Kg})\end{array}$ & 514.92 & 399.25 & 210.50 & 469.87 \\
\hline Selling price per kg (RM) & 240.50 & 128.20 & 105.50 & 158.06 \\
\hline \multicolumn{5}{|l|}{ Age distribution(year) } \\
\hline - $20-29$ & $31.0 \%(\mathrm{n}: 27)$ & $12.0 \%(\mathrm{n}: 3)$ & $8.3 \%(\mathrm{n}: 1)$ & $25.0 \%(n: 31)$ \\
\hline - $\quad 30-39$ & $37.9 \%(n: 33)$ & $32.0 \%(\mathrm{n}: 8)$ & $33.3 \%(\mathrm{n}: 4)$ & $36.3 \%(n: 45)$ \\
\hline - $40-49$ & $12.6 \%(\mathrm{n}: 11)$ & $20.0 \%(\mathrm{n}: 5)$ & $33.3 \%$ (n: 4) & $16.1 \%(n: 20)$ \\
\hline - 50 above & $18.4 \%(\mathrm{n}: 16)$ & $36.0 \%$ (n: 9) & $25.0 \%(\mathrm{n}: 3)$ & $22.6 \%(n: 28)$ \\
\hline \multicolumn{5}{|l|}{ Educational level } \\
\hline - No education & $0.0 \%(\mathrm{n}: 0)$ & $0.0 \%(\mathrm{n}: 0)$ & $25 \%(\mathrm{n}: 3)$ & $2.4 \%(n: 2)$ \\
\hline - Primary school & $1.1 \%(\mathrm{n}: 1)$ & $20.0 \%(\mathrm{n}: 5)$ & $41.7 \%$ (n: 5) & $8.9 \%(n: 11)$ \\
\hline $\begin{array}{ll}\text { High } & \text { school } \\
(\mathrm{SPM}) & \end{array}$ & $26.4 \%(\mathrm{n}: 23)$ & $56.0 \%(\mathrm{n}: 14)$ & $0 \%(\mathrm{n}: 0)$ & $29.8 \%(n: 37)$ \\
\hline
\end{tabular}


Bees Farming in Malaysia

\begin{tabular}{|c|c|c|c|c|}
\hline Variables/Area & $\begin{array}{r}\text { Peninsular } \\
\text { Malaysia }\end{array}$ & Sarawak & Sabah & Malaysia \\
\hline University/college & $72.4 \%$ (n: 63$)$ & $24.0 \%$ (n: 6$)$ & $33.3 \%(\mathrm{n}: 4)$ & $58.9 \%(n: 73)$ \\
\hline \multicolumn{5}{|l|}{ Experience } \\
\hline - 1 year & $28.7 \%(\mathrm{n}: 25)$ & $12.0 \%(\mathrm{n}: 3)$ & $25.0 \%(\mathrm{n}: 3)$ & $25.0 \%(n: 31)$ \\
\hline - Above 1year & $71.3 \%(\mathrm{n}: 62)$ & $88.0 \%$ (n: 22$)$ & $75.0 \%(\mathrm{n}: 9)$ & $75.0 \%(\mathrm{n:}: 93)$ \\
\hline \multicolumn{5}{|l|}{ Job } \\
\hline - Beekeeping & $13.8 \%(\mathrm{n}: 12)$ & $76.0 \%$ (n: 19$)$ & $17.0 \%(\mathrm{n}: 2)$ & $25.8 \%(\mathrm{n}: 32)$ \\
\hline - Part- time job & $87.4 \%$ (n: 76$)$ & $24.0 \%(\mathrm{n}: 6)$ & $83.0 \%$ (n: 10$)$ & $74.2 \%(n: 92)$ \\
\hline
\end{tabular}

The expenditure of initial investment in starting a new project of stingless honey bees was presented in Table 3. Table 3 below elaborated the regular item of assets in relating honey's production. In most cases, the asset would perform a stingless bee project for more than 5 years and about 13 fixed expenditure items should be prepared to start the project, namely hive, overall custom, chainsaw, battery, hive base, new flower plants, etc. Total Hive expenditure is approximately RM 47,796.21 for 115 hives in Malaysia. Meanwhile, Peninsular Malaysia paid the highest total expenses of hives at RM 64,607.18. It reflected that total expenditures were expended considerably in the area of Peninsular Malaysia (RM 89,119.76), reflecting the starting project of stingless honey bees is slightly expensive for the peninsula. On the other hand, Sabah region seems more affordable in purchasing the overall initial project as costing about RM 18,405.45.

Table 3: Initial Investment in Building Stingless Bees Project

\begin{tabular}{lrrrr}
\hline \hline Investment items & $\begin{array}{r}\text { Peninsular } \\
\text { Malaysia }\end{array}$ & Sarawak & Sabah & Malaysia \\
\hline Hives & $64,607.18$ & $9,192.20$ & $6,508.33$ & $\mathbf{4 7 , 7 9 6 . 2 1}$ \\
Overall custom & 162.39 & 189.17 & - & $\mathbf{1 6 6 . 7 3}$ \\
Suction machine & 405.96 & 496.96 & 226.88 & $\mathbf{4 1 2 . 0 2}$ \\
Honey container & 150.95 & 105.41 & 50.00 & $\mathbf{1 3 2 . 6 8}$ \\
Chainsaw & $1,432.99$ & $1,623.50$ & $1,220.91$ & $\mathbf{1 , 4 4 8 . 0 6}$ \\
Battery & 93.85 & 187.50 & 37.20 & $\mathbf{1 1 7 . 9 4}$ \\
New flower plants & $1,561.07$ & 612.73 & 450.00 & $\mathbf{1 , 3 3 1 . 0 0}$ \\
Cabin & $1,300.00$ & $5,000.00$ & - & $\mathbf{2 , 0 4 0 . 0 0}$ \\
Store & $11,062.50$ & $4,800.00$ & - & $\mathbf{1 0 , 0 7 3 . 6 8}$ \\
Hive base & $1,161.37$ & $1,766.07$ & $5,200.00$ & $\mathbf{1 , 4 1 1 . 4 6}$ \\
Gate & $5,694.78$ & $2,700.00$ & $4,650.00$ & $\mathbf{5 , 2 0 9 . 6 6}$ \\
Cap and veil & 89.57 & 27.89 & 48.00 & $\mathbf{7 4 . 0 0}$ \\
Gloves & 27.15 & 20.21 & 14.14 & $\mathbf{2 4 . 8 0}$ \\
Others & $1,450.00$ & $1,059.17$ & - & $\mathbf{1 , 1 5 6 . 8 8}$ \\
Total Initial Investment $(\mathbf{R M})$ & $\mathbf{8 9 , 1 9 9 . 7 6}$ & $\mathbf{2 7 , 7 8 0 . 8 0}$ & $\mathbf{1 8 , 4 0 5 . 4 6}$ & $\mathbf{7 1 , 3 9 5 . 1 1}$ \\
\hline \hline
\end{tabular}

Then, Figure 3 below illustrated the percentage proportion of initial investment in procuring the initial fixed assets of stingless bees project. Accordingly, purchasing log hives listed as a high expenditure of assets, approximately $72 \%$ from the total investment in Malaysia. Similarly, all regions also showed that buying hives were the major expenses of starting the project, but the cost proportion of Sabah and Sarawak were lower than Peninsular Malaysia, indicating the price of hive offered considerably cheaper than the Peninsular. Then, general equipment in effecting direct 
production, namely chainsaw, battery, honey container, suction machine, hive base and new flower plant contributed below $30 \%$ of the total asset expenditure. Therefore, it is assumed that in order to start a stingless bees project, a capital asset is highly contributed by the price of a hive, if the beekeeper could find inexpensive log hive, the total amount of invested money for the project may be more affordable, mainly for the people who eager to do a business but with limited access of fund.

Figure 3: The Distribution of Initial Investment of Stingless Bees Farming

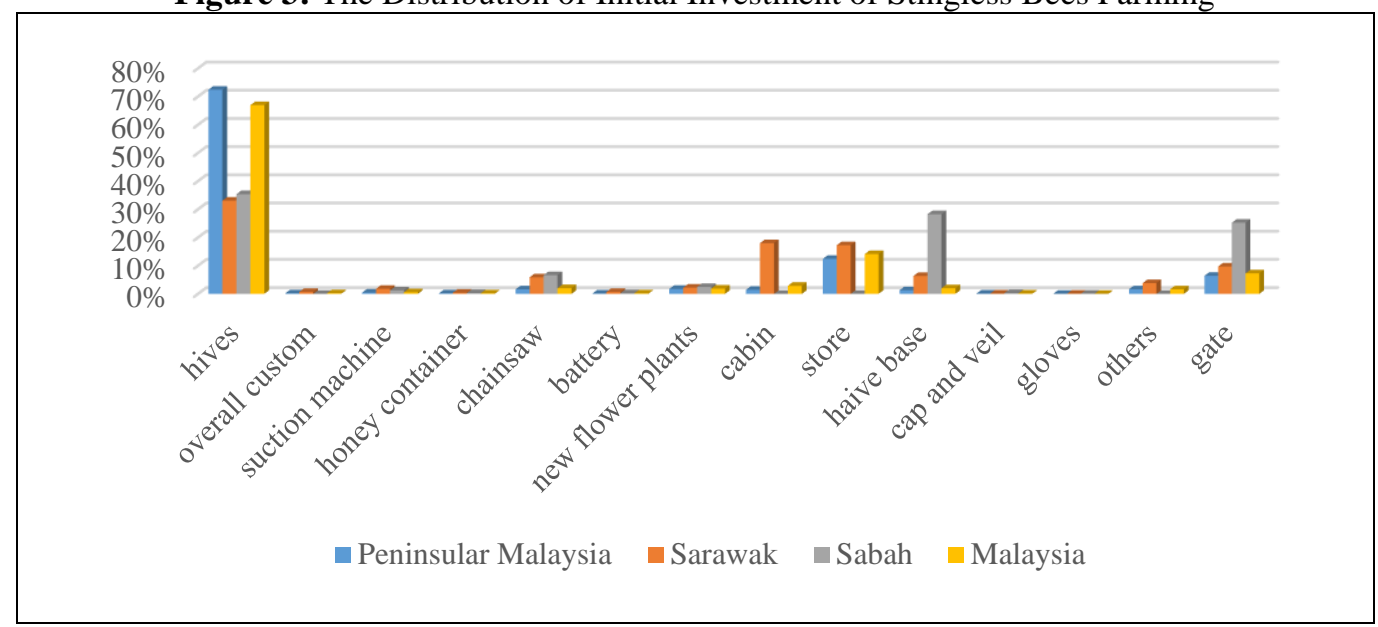

The list of total cost information of stingless bees farming illustrated particularly in the Table 4 below. The cost consists of others fixed, variable and depreciation costs during spending in oneyear production. The fixed cost of the project solely included utility cost, wherein it was combined by spending on phone credit, water and electric bills. Then, a deduction of total initial investment for 10-year projection was computed to the cost of depreciation and any expenses which effect directly to the number of honey production, namely vitamin, sickness portion, diesel, petrol and labor cost, were explained as variable items. Based on Table 4, the total cost for 1-year project of stingless honey bees was RM 40,104.73 and variable cost in producing $469.87 \mathrm{~kg}$ of honey was RM 32,087.39. In term of regions, the higher cost was presented by Peninsular Malaysia at RM 56,202.65, followed by Sarawak (RM 17,441.71) and Sabah (RM 14,273.47).

Table 4: Total Cost of Stingless Bees Project in a Year

\begin{tabular}{lccrr}
\hline \hline Expenses & $\begin{array}{c}\text { Peninsular } \\
\text { Malaysia }\end{array}$ & Sarawak & Sabah & Malaysia \\
\hline Utilities & $\begin{array}{c}\text { Fixed Cost } \\
901.78\end{array}$ & $1,245.00$ & 517.20 & $\mathbf{8 7 7 . 3 3}$ \\
& $\begin{array}{c}\text { Depreciation Cost } \\
\text { Depreciation of assets }\end{array}$ & & & \\
& $8,919.98$ & $2,778.08$ & $1,840.55$ & $\mathbf{7 , 1 3 9 . 5 1}$ \\
Vitamin & Variable Cost & & - & $\mathbf{2 , 2 0 0 . 0 0}$ \\
Total labor cost (RM) & $2,200.00$ & - & $8,100.00$ & $\mathbf{2 4 , 4 9 0 . 4 3}$
\end{tabular}




\begin{tabular}{lrrrr}
\hline \hline Expenses & $\begin{array}{c}\text { Peninsular } \\
\text { Malaysia }\end{array}$ & Sarawak & Sabah & Malaysia \\
\hline Sickness portion & $1,368.00$ & $1,207.20$ & 300.00 & $\mathbf{1 , 1 9 7 . 8 2}$ \\
Pesticides cost (RM) & 456.00 & $1,820.00$ & $1,875.00$ & $\mathbf{9 0 3 . 1 0}$ \\
Petrol cost/transport (RM) & $2,767.20$ & $1,220.00$ & 440.73 & $\mathbf{2 , 0 9 6 . 5 4}$ \\
Diesel cost (RM) & - & $1,200.00$ & $1,200.00$ & $\mathbf{1 , 2 0 0 . 0 0}$ \\
Other cost (RM) & - & - & - & $\mathbf{0 . 0 0}$ \\
Total cost variable cost year & $46,381.20$ & $13,418.63$ & $11,915.73$ & $\mathbf{3 2 , 0 8 7 . 8 9}$ \\
Total cost per year & $56,202.95$ & $17,441.71$ & $14,273.47$ & $\mathbf{4 0 , 1 0 4 . 7 3}$ \\
\hline \hline
\end{tabular}

Notes: Total cost per year equals the sum of fixed, depreciation and variables costs.

Then, Table 5 described the cost of stingless honey bees based on unit $/ \mathrm{kg}$. About RM 1.87 was only consumed by fixed cost for producing 1 kilogram of honey. Accordingly, depreciation cost paid at RM 15.19 per $\mathrm{kg}$ in Malaysia. On the other hand, variable cost per $\mathrm{kg}$ of honey was RM 68.29, indicating changing of the variable cost would be significantly affected the return of producing $1 \mathrm{~kg}$ honey. The total cost of attaining $1 \mathrm{~kg}$ of honey seemed more expensive for the Peninsular Malaysia (RM 109.15), followed by Sabah at RM 67.81 and Sarawak at RM43.69, respectively.

Table 5: Cost per $\mathrm{Kg}$ of Stingless Honey Bees

\begin{tabular}{lccrr}
\hline \hline Expenses & $\begin{array}{c}\text { Peninsular } \\
\text { Malaysia }\end{array}$ & Sarawak & Sabah & Malaysia \\
\hline Utilities & $\begin{array}{c}\text { Fixed Cost } \\
\text { Depreciation cost }\end{array}$ & 3.12 & 2.46 & $\mathbf{1 . 8 7}$ \\
Depreciation of assets & 18.98 & 6.96 & 8.47 & $\mathbf{1 5 . 1 9}$ \\
& Variable cost & & - & $\mathbf{4 . 6 8}$ \\
Vitamin & 4.27 & -9.97 & 38.48 & $\mathbf{5 2 . 1 2}$ \\
Total labor cost (RM) & 76.89 & 3.02 & 1.43 & $\mathbf{2 . 5 5}$ \\
Sickness portion & 2.66 & 4.56 & 8.91 & $\mathbf{1 . 9 2}$ \\
Pesticides cost (RM) & 0.89 & 3.06 & 2.09 & $\mathbf{4 . 4 6}$ \\
Petrol cost/transport (RM) & 5.37 & 3.01 & 5.70 & $\mathbf{2 . 5 5}$ \\
Diesel cost (RM) & - & - & - & - \\
Other cost (RM) & - & 33.61 & 56.61 & $\mathbf{6 8 . 2 9}$ \\
Total variable cost per kg & 90.08 & 43.69 & 67.81 & $\mathbf{8 5 . 3 5}$ \\
Total cost per kg & 109.15 & & \\
\hline \hline
\end{tabular}

Notes: Variable cost per kg equals cost divided by total production in $\mathrm{kg}$

The distribution of total cost in a stingless bees' project was illustrated in Figure 4. It has shown that labor cost was a predominant expense in an annual production cycle, constituting almost $70 \%$ of the total cost. It followed similarly to all regions in Malaysia; nevertheless, the Sarawak region was more efficient in terms of paying its labor usage for honey production. Then, depreciation cost also considered being the second concern of total cost in the stingless bee project, even though the cost of depreciation is indirectly affected the production cost. Furthermore, other expenses such as vitamin, sickness portion, petrol, diesel and utility cost contributed slightly inexpensive to the total expenses of the project in a year. 
Figure 4: The Distribution of Total Cost in Stingless Bees Project

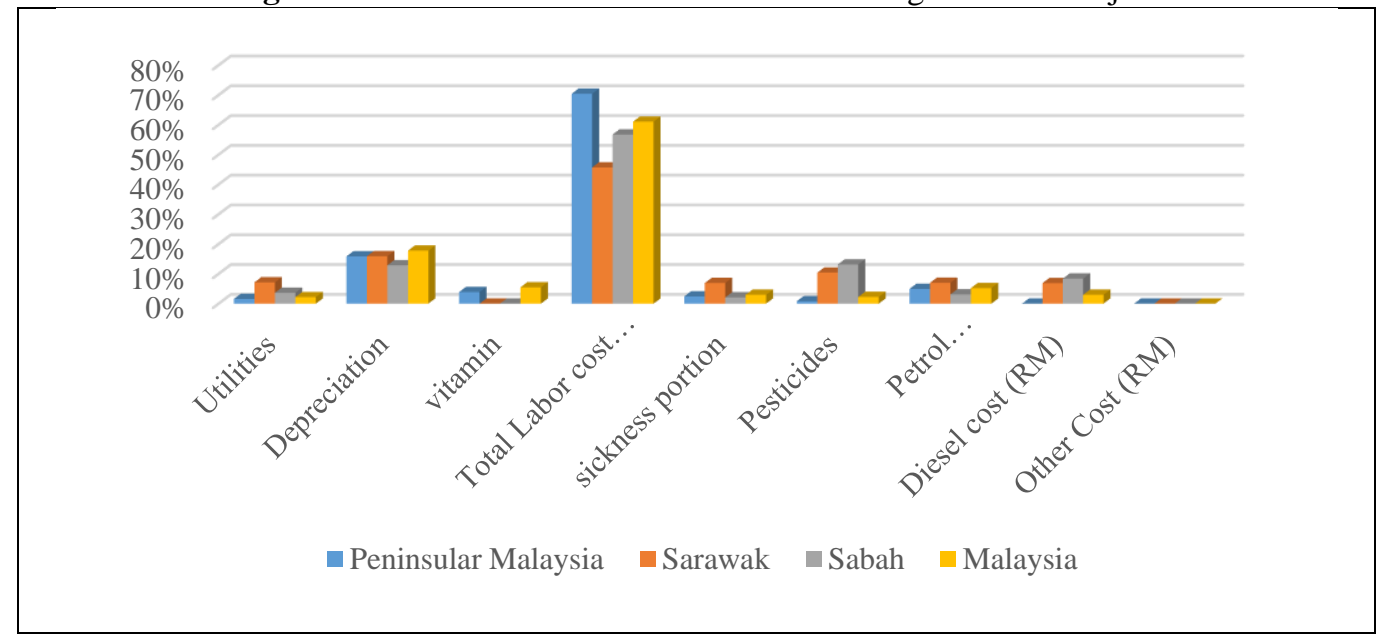

Table 6 showed the net income of stingless bees farming in a year. The formulation of net income of the project is total cost (fixed, depreciation and variable costs) deficient total revenue. Total revenue is computed by the number of honey production per year, multiplied price of honey per kilogram. As Table 4.5 shown, the net profit of selling stingless honey' bees was RM 34,166.31 per year in Malaysia. This value may generate income per month about RM 2,847.19 and approximated profit per kilogram of honey at RM 72.71. In terms of area, Peninsular Malaysia seemed more lucrative in receiving a net profit of stingless bees' project, it constituted as gaining income about RM 67,634.28 per year, an approximated monthly income of 5,636.19 and RM 131.35 profit per kilogram.

Table 6: Net Return for Stingless Bees Farming

\begin{tabular}{lrrrr}
\hline \hline Entities & \multicolumn{1}{c}{$\begin{array}{c}\text { Peninsular } \\
\text { Malaysia }\end{array}$} & \multicolumn{1}{l}{ Sarawak } & \multicolumn{1}{l}{ Sabah } & \multicolumn{1}{c}{ Malaysia } \\
\hline a. Total revenue & $123,837.23$ & $51,184.26$ & $22,207.75$ & $\mathbf{7 4 , 2 7 1 . 0 5}$ \\
b. Total fixed cost & 901.78 & $1,245.00$ & 517.20 & $\mathbf{8 7 7 . 3 3}$ \\
c. Depreciation cost & $8,919.98$ & $2,778.08$ & $1,840.55$ & $\mathbf{7 , 1 3 9 . 5 1}$ \\
d. Total variable cost & $46,381.20$ & $13,418.63$ & $11,951.73$ & $\mathbf{3 2 , 0 8 7 . 8 9}$ \\
e. Total cost (b+c+d) & $56,202.95$ & $17,441.71$ & $14,273.47$ & $\mathbf{4 0 , 1 0 4 . 7 3}$ \\
Net profit (a-e) & $67,634.28$ & $33,742.55$ & $7,934.28$ & $\mathbf{3 4 , 1 6 6 . 3 1}$ \\
Net profit per Kg (RM) & 131.35 & 84.51 & 37.69 & $\mathbf{7 2 . 7 1}$ \\
Esitimated monthly income & $5,636.19$ & $2,811.88$ & 661.19 & $\mathbf{2 , 8 4 7 . 1 9}$ \\
(RM) & & & & \\
\hline \hline
\end{tabular}

Notes: Total revenue is quantity of honey production per year multiplied by price of honey per $\mathrm{kg}$

Net profit is total revenue subtracts total fixed, variable and depreciation costs

Net profit per kg equals net profit divided by total kilogram sold per year

Estimated monthly income is net profit divided by number of months in a year

Subsequently, Table 7 illustrated the average net return of stingless bees farming with tax obligations. Commonly, the tax burden only imposed on the large company with the revenue is more than 2.5 million in Malaysia tax policy. However, in the following Table, the study tried to 
simulate tax obligation, as the purpose for estimating the calculation whether the project is still profitable or not. As Table 4.6 elaborated, the stingless bees farming imposed tax burden in a year RM 8,541.58 which affected net profit to be RM 25,624.73 per year. This circumstance would also reduce monthly income at RM 2,135.39 from the initial income as 2,847.19 per month and net profit RM 54.54 per $\mathrm{kg}$ which loss about RM 17 per kg from the profit of tax exemption. Similarly, by applying tax duty in the net income for three regions in Malaysia, the area of Peninsular Malaysia was still receiving high stable income, constituting either RM 50,725.71 per year, RM 4,277.14 per month or RM 98.51 per kilogram respectively, while stingless bee farm in Sabah gained the lowest profit among the three regions in Malaysia.

Table 7: Net Return for Stingless Bees Farm with the Common Corporate Tax Rate

\begin{tabular}{|c|c|c|c|c|}
\hline Entities & Peninsular Malaysia & Sarawak & "Sabah & "Malaysia \\
\hline Total revenue & $123,837.23$ & $51,184.26$ & $22,207.75$ & $74,271.05$ \\
\hline b. Total fixed cost & 901.78 & $1,245.00$ & 517.20 & 877.33 \\
\hline c. Total depreciation cost & $8,919.98$ & $2,778.08$ & $1,840.55$ & 7,139.51 \\
\hline Total variable cost & $46,381.20$ & $13,418.63$ & $11,951.73$ & $32,087.89$ \\
\hline e. Total cost $(b+c+d)$ & $56,202.95$ & $17,441.71$ & $14,273.47$ & $40,104.73$ \\
\hline f. $\quad$ EBT $(a-e)$ & $67,634.28$ & $33,742.55$ & $7,934.28$ & $34,166.31$ \\
\hline g. $\quad$ Tax $\left(\mathrm{EBT}^{*} 25 \%\right)$ & $16,908.57$ & $8,435.64$ & $1,983.57$ & $8,541.58$ \\
\hline h. $\quad$ EAT $(f-g)$ & $50,725.71$ & $25,306.91$ & $5,950.71$ & $25,624.73$ \\
\hline Net profit per $\mathrm{Kg}(\mathrm{RM})$ & 98.51 & 63.39 & 28.27 & 54.54 \\
\hline Esitimated montly income (RM) & $4,227.14$ & $2,108.91$ & 495.89 & 2,135.39 \\
\hline
\end{tabular}

Notes: Total revenue is quantity of honey production per year multiplied by price of honey per $\mathrm{kg}$

EBT stands for Earning Before Tax and EAT is Earning After Tax

Net profit per kg equals net profit divided by total kilogram sold per year

Estimated monthly income is net profit divided by number of months in a year

The input-output and cost-benefit ratios of stingless bees farming were presented in Table 8 . Both ratios used to determine returns and efficiency. The computation was applied by dividing the revenue or profit with the total cost. The result showed that the input-output ratio of stingless bee farm in Malaysia was 1.85, indicating each ringgit of input expensed in the farm will receive the benefit of 85 cents. Then, by comparing with all regions in Malaysia, even though the Peninsula attained more revenue (output), its ratio showed lower than Sarawak as 2.93 or 1.93, indicating beekeepers in Sarawak were having more efficient farm management system and its benefit exceeded the cost. However, this assumption also emphasized by Khair (2002) that the high return of income is not necessarily being the most profitable farm.

Table 8: Value of Input-Output and Cost-Benefit Ratio in Stingless Honey Bees Farming

\begin{tabular}{lrrrr}
\hline \hline Items & \multicolumn{1}{c}{$\begin{array}{c}\text { Peninsular } \\
\text { Malaysia }\end{array}$} & \multicolumn{1}{l}{ Sarawak } & \multicolumn{1}{l}{ Sabah } & \multicolumn{1}{c}{ Malaysia } \\
& $123,837.23$ & $51,184.26$ & $22,207.75$ & $\mathbf{7 4 , 2 7 1 . 0 5}$ \\
Total revenue (RM) & $56,202.95$ & $17,441.71$ & $14,273.47$ & $\mathbf{4 0 , 1 0 4 . 7 3}$ \\
Total rost (RM) & $67,634.28$ & $33,742.55$ & $7,934.28$ & $\mathbf{3 4 , 1 6 6 . 3 1}$ \\
Net Profit (RM) & $\mathbf{2 . 2 0}$ & $\mathbf{2 . 9 3}$ & $\mathbf{1 . 5 6}$ & $\mathbf{1 . 8 5}$ \\
Input-output ratio & $\mathbf{1 . 2 0}$ & $\mathbf{1 . 9 3}$ & $\mathbf{0 . 5 6}$ & $\mathbf{0 . 8 5}$ \\
Cost-benefit ratio & & & & \\
\hline \hline
\end{tabular}


Figure 5 below illustrated how the stingless bee farm should be aware of the interaction of cost, volume and profit by evaluating the break-even point analysis. Break-even point is the relationship of cost behaviour and sales volume that helps farm managers to predict, evaluate and plan any changes in business operation in order to obtain sufficient revenue in covering all costs. Figure 4.3 showed that the total fixed and depreciation costs were stable at RM 8,016.84 per year in Malaysia. These costs, however, would not affect a number of productions in a year, which the farm should pay frequently although there is no business operation. On the other hand, the behaviour of variable cost would make a linear trend to the number of unit production, as the figure of variable cost in producing $469.87 \mathrm{~kg}$ of honey was RM 32,087.89 in Malaysia. Then, the figure below also pointed out the line of revenue at RM 74,271.05 for selling $469.87 \mathrm{~kg}$ of honey in Malaysia. Hence, by analyzing the break-even point of this circumstance, in order to cover up all costs during a year operation and avoid losses, the stingless bee farm should produce at least $89.30 \mathrm{~kg}$ of honey. At this point, however, the farm would not generate profit, whilst profit would start after the farm production exceeded honey quantity more than $89.30 \mathrm{~kg}$. As an illustration, by producing 89.30 $\mathrm{kg}$ of honey, it generates variable cost to RM 6,098 (variable cost per kg x quantity) and RM 8,016 for fixed and depreciation costs. Then, the total cost of $89.30 \mathrm{~kg}$ of honey becomes approximately RM 14,114 (variable + fixed + depreciation). By selling it with price at RM 158 would receive the income of about RM 14,114 (price per kg x quantity). In this circumstance, the farm would attain breakeven (no profit or no loss). Therefore, if stingless bee farm increased production to $90 \mathrm{~kg}$ per year, the increase of revenue would be RM 14,225 (90 kg x RM 158.06), while the total cost slightly rise as RM 14,162 (RM 8,016 + RM 6,146). Then, the approximated profit would be apparently positive at RM 62 (RM 14,225 - RM 14,162).

Figure 5: Break even analysis of stingless bee farms in Malaysia

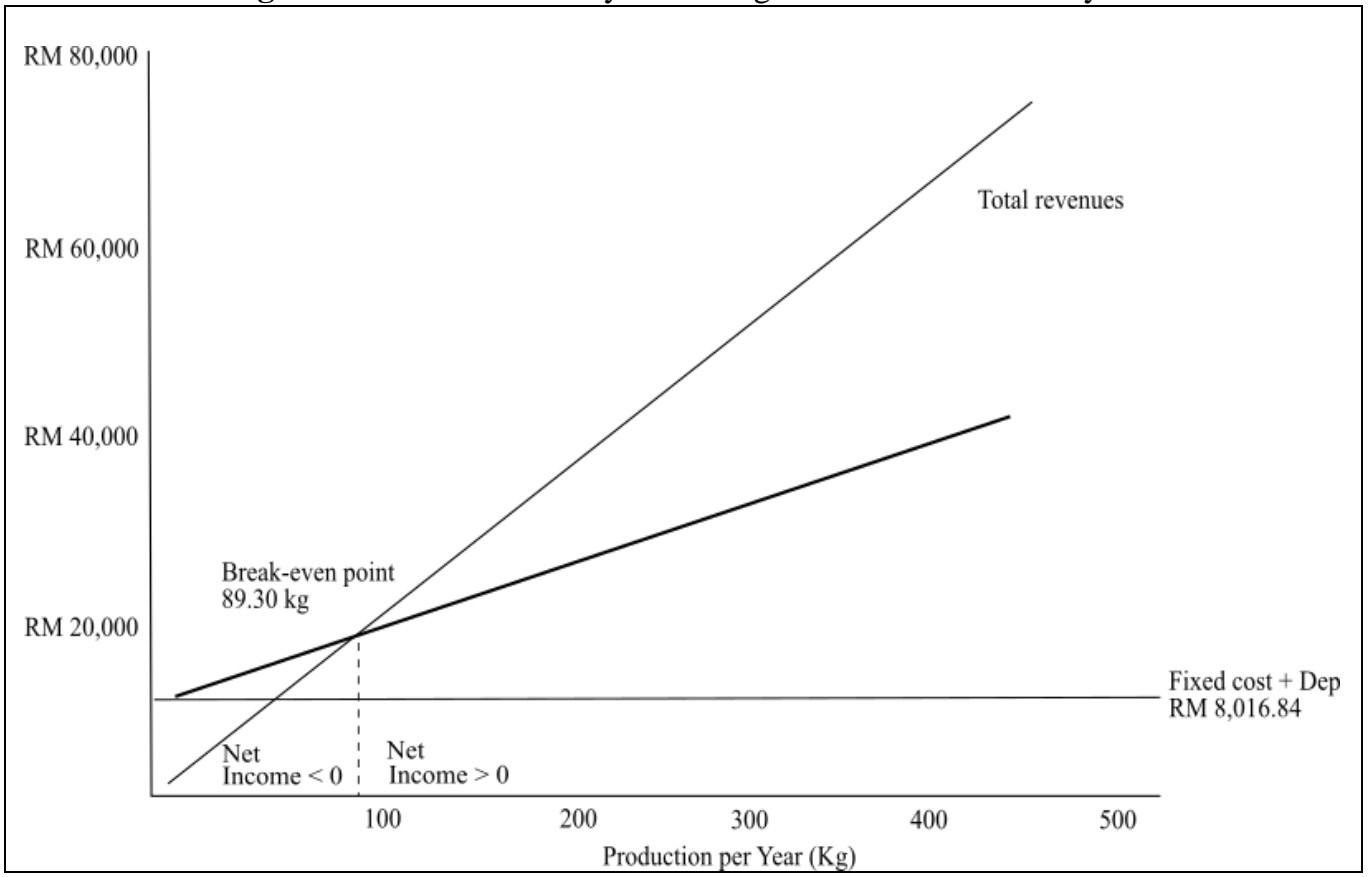


Figure 6, 7 and 8 respectively illustrated the break-even point of stingless bee production based on regions, namely Peninsular Malaysia, Sabah and Sarawak. Figure 6 showed the break-even point in Peninsular Malaysia was $65.29 \mathrm{~kg}$, indicating the Peninsula farm should produce stingless bee honey at least more than $66 \mathrm{~kg}$ per year of honey in order to make a profit. Then, based on Figure 7, Sabah farm must sell $48.22 \mathrm{~kg}$ of honey to cover the RM 2,357.73 in fixed and depreciation costs, while in order to cover up fixed and depreciation cost of RM 4,023.08 in a year, Sarawak bee farm requires $42.53 \mathrm{~kg}$ of honey production (Figure 8). By comparing three regions in terms of break-even production, it assumes that the Sarawak region seems more effective in adjusting earnings from the impact of marketing activity with a lower risk.

Figure 6: Break even analysis of stingless bee farms in Peninsular Malaysia

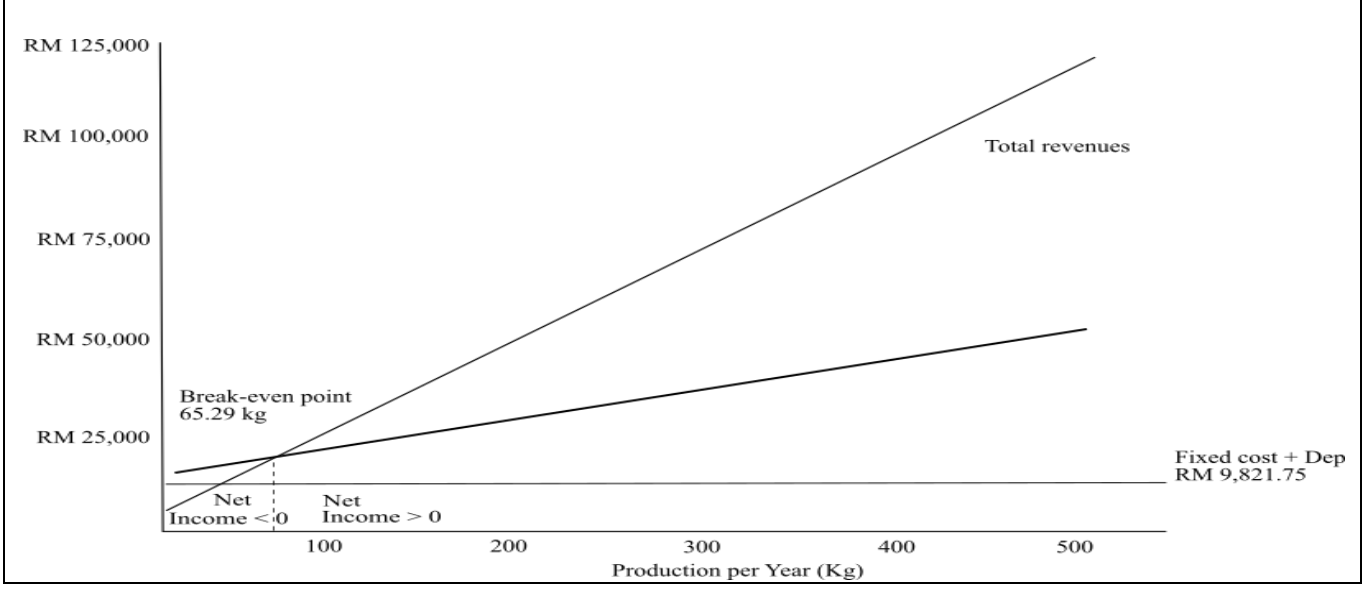

Figure 7: Break even analysis of stingless bee farms in Sabah

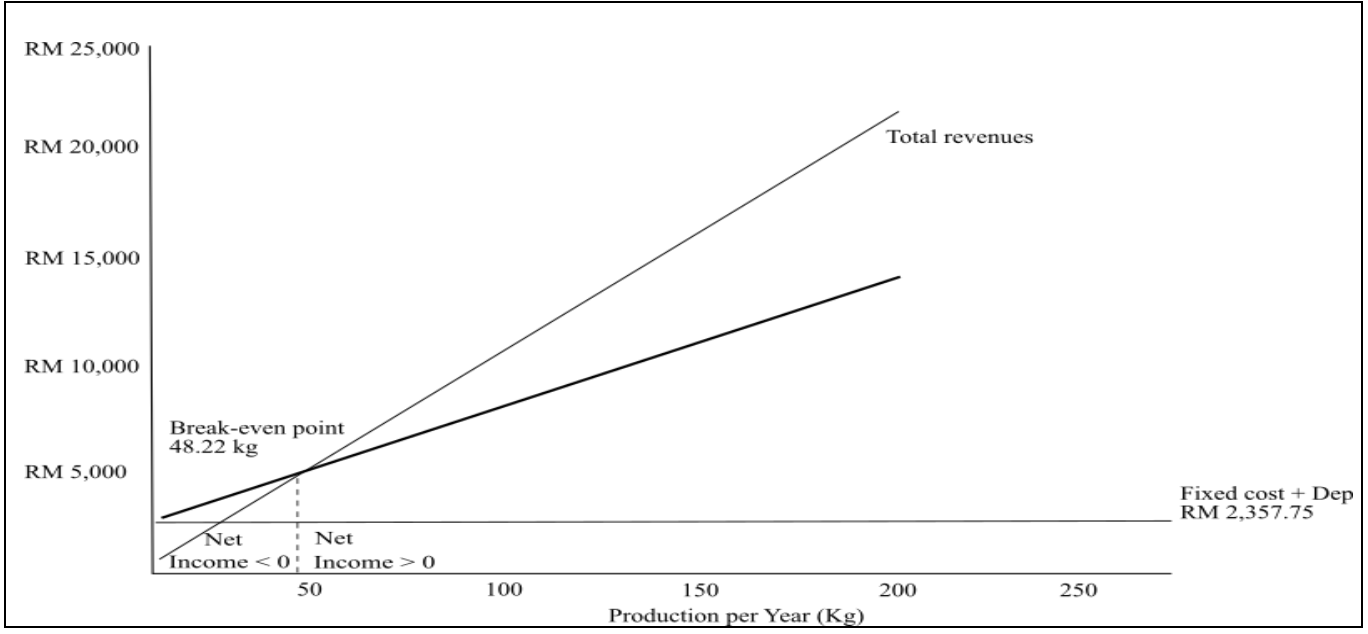


Figure 8: Break even analysis of stingless bee farms in Sarawak

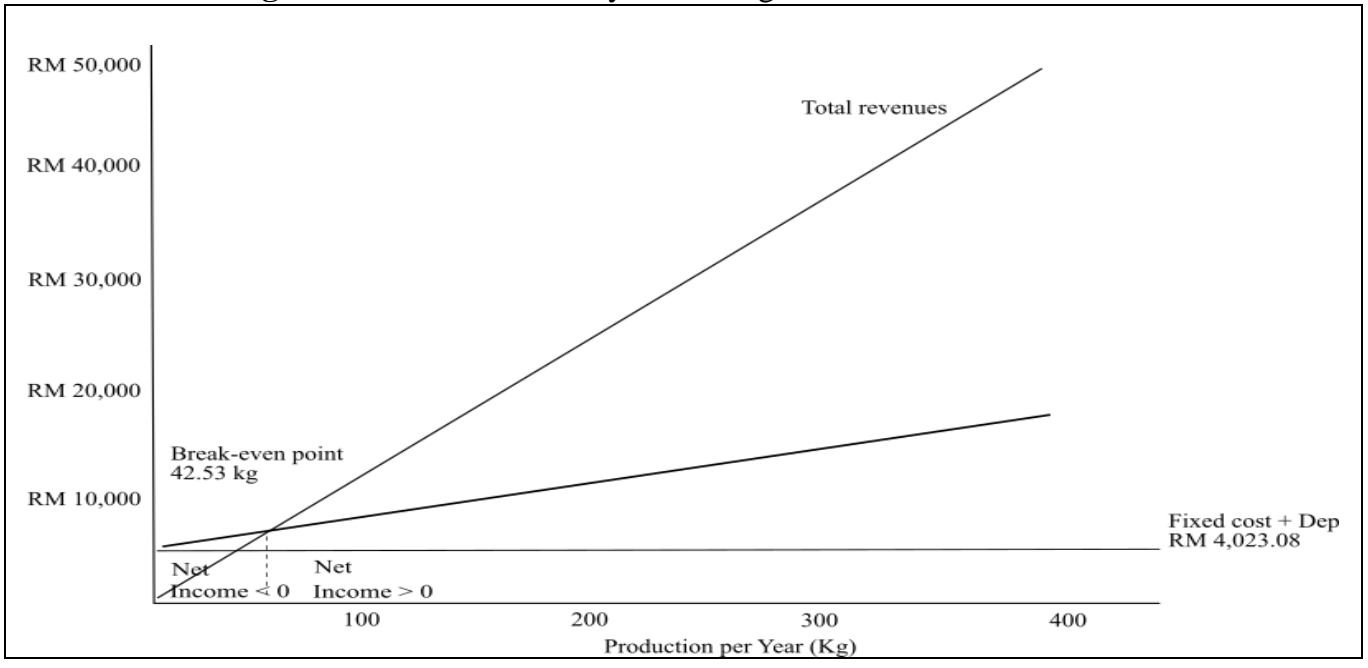

\section{CONCLUSION}

The Trigona or stingless bee is a new activity in the beekeeping industry that could complement natural honey production and pollination services. The potential of Trigona is tremendous and urgently need further research due to the high demand and lack of supply in Malaysia. In terms of cost-benefit outcomes, in order to start a new project of a stingless honey's bee, the expenditure of hive constituted as a high initial investment, while the hive price in Peninsular Malaysia is more expensive than the Sarawak and Sabah regions. Then, the cost of labor has to be a prior concern in the total cost of production because the cost was a major contribution during expenses in a month or a year. Based on the net return, the stingless bee farming may generate considerable profit at RM 72.71 per kg in Malaysia. Then, the region in Peninsular Malaysia earned higher profit, while the Sarawak farm showed more efficient farm management and more effective in generating earnings from the impact of marketing activity with a lower risk. The policy recommendation may be suggested if the stingless bees farming along with a government assistance would minimize the use of labor in the production system by providing new technology in the farm management as introducing modern hive in limited land size. Moreover, the adapted technology of hive would also reduce capital expenditure and make the industry more efficient since the hive cost listed as a major contribution to the initial investment of the stingless bees' project. Then, the modern hive would solely multiply colony, hence, it would generate efficient farming and minimize the usage of the $\log$ that would lead to forest conservation.

\section{ACKNOWLEDGEMENT}

The authors thankfully acknowledge the financial support received from the TRGS research grant no. TRGS/1/2016/UPM/01/5/1 provided by the Ministry of Education, Malaysia. 


\section{REFERENCES}

Abdurofi, I., Ismail, M. M., Abdul-Wahab, K. H., \& Gabdo, B. H. (2017). Economic analysis of broiler production in Peninsular Malaysia. International Food and Research Journal, 24(2), 761-766.

Andualem, B. (2014). Physico-chemical, microbiological and antibacterial properties of Apis mellipodae and Trigona spp. honey against bacterial pathogens. World Journal of Agricultural Sciences, 10(3), 112-120.

Berryman, C. W., \& Nobe, M. D. (1999). Practical business application of break-even analysis in graduate construction education. Journal of Construction of Education, 4(1), 26-37.

Boelje, M. D., \& Eidman, V. R. (1984). Farm management. New York: John Wiley and Sons. United States America.

Budiaman. (2016). Financial feasibility analysis of agroforestry by Trigona spp Honey bee Based. https://core.ac.uk/download/pdf/25496882.pdf

Ismail, M. M. (2014). Competitiveness of beekeeping industry in Malaysia. Universiti Putra Malaysia Press. https://psasir.upm.edu.my/id/eprint/41608/2/COMPETITIVENESS.pdf

Ismail, M. M., \& Radam, A. (2010). Measuring the effect of Asian financial crisis on the comparative advantage of the food processing industry. International Journal of Economics and Management, 4(2), 279 - 296.

Khair, S. M. (2002). Cost of production and constraints of broiler production in Pishin, Balochistan. Pakistan Journal of life and Social Science, 3(2), 43-47.

Jalil, A. H. (2016). World meliponine etymology of taxonomic nomenclature. Akademi Kelulut Malaysia Sdn Bhd, Bandar Baru Bangi, Selangor.

Jalil, A. H., \& Roubik, D. W. (2016). Handbook of Meliponiculture, Indo-Malayan stingless bees. Akademi Kelulut Malaysia Sdn Bhd, Bandar Baru Bangi, Selangor

Jalil, A. H., \& Shuib, I. (2014). Beescape for meliponines - conservation of indo-malayan stingless bees. Partridge Publishing

Narjes, M. E. (2009). Is beekeeping a viable additional income for the rural poor? Institute of Farm Management, University of Hohenheim, Germany.

Ndaliman, B. M., \& Bala, K. C. (2007). Practical limitations of break-even theory. AU.J.T, 11(1), 58-61.

Nurunnaher., Rahman., K. M., \& Ali, M. H. (2003). Productivity and efficiency measurement of rice production by member and non-member farmers in selected cooperative societies of Bangladesh. Economic Affairs, 48(4), 220.

Olukosi, J. O., \& Erhabor, P. O. (1987). Introduction to Farm Management Economics: Principles and Applications. Zaria: Agitab Publishers.

Pollack, B. (1995). Break-even analysis: The third leg of the underwriting stool. Real Estate Review, 25, 43-46.

Powers, T. L. (1987). Break-even analysis with semi-fixed cost. Industrial Marketing Management, 16(1), 35-41.

Roubik, D. W. (2006). Stingless bee nesting biology. Apidologie, 37, 124-143. 